\title{
SENSORY EVALUATION AND CHARACTERIZATIONS OF EMULSION CONTAINING SODIUM CHLORIDE AND ITS APPLICATION IN CORN SOUP
}

\author{
[Evaluasi Sensori dan Karakterisasi Emulsi Mengandung Natrium Klorida \\ dan Aplikasinya pada Sup Jagung]
}

\author{
Melanie Cornelia ${ }^{1) \star}$, Irene Triyanti ${ }^{2)}$, Teguh Prasetia ${ }^{2)}$, and Cathy Purnomo ${ }^{1)}$ \\ 1) Food Technology Department, Pelita Harapan University, Tangerang \\ 2) Food Research and Development Department, PT. Nutrifood Indonesia, Bogor
}

Approved August $14^{\text {th }} 2016 /$ Accepted November $25^{\text {th }} 2016$

\begin{abstract}
Reduction of sodium chloride in food products has been reported to lower consumers' acceptance. In this research, the physical characteristics and sensory property of an oil in water emulsion containing sodium chloride, as well as its application in corn soup were studied. The $\mathrm{m}$ ain objectives of this this research were to evaluate salt reduction that could be achieved through emulsion and to obtain a stable emulsion with most applicable viscosity for corn soup. In research stage I, three different oil concentrations $(23,28$, and $33 \%)$ with constant salt and stabilizers concentration were applied into the emulsions. The result showed that emulsion with $33 \%$ oil was significantly more viscous than the others, whilst emulsion with $23 \%$ oil was found to be less salty than the others $(\alpha=0.05)$. Emulsion with $28 \%$ oil content was chosen for research stage II due to appropriate saltiness and viscosity. In research stage II, different types and concentrations of thickening agent ( 1 and $2 \%$ tapioca; 0.1 and $0.2 \%$ xanthan gum), and emulsifier concentration $(0.5,1.0$, and $1.5 \%$ Soy Protein Isolate) were applied into the emulsions with $28 \%$ oil. The viscosity and stability of emulsion were significantly affected by the concentration of stabilizers. Emulsion with $28 \%$ oil content, $0.1 \%$ xanthan gum and $0.5 \%$ SPI was applied into corn soup. As a result, $25 \%$ reduction in sodium chloride could be achieved without significantly decreasing saltiness.
\end{abstract}

Keywords: corn soup, o/w emulsion, salt reduction, sensory evaluation, sodium chloride

\begin{abstract}
ABSTRAK
Pengurangan jumlah natrium klorida yang dipakai dalam produk pangan menyebabkan penurunan penerimaan konsumen. Dalam penelitian ini, dilakukan evaluasi karakteristik fisik dan sensori emulsi minyak dalam air yang mengandung natrium klorida yang diaplikasikan dalam sup jagung. Tujuan penelitian ini untuk mendapatkan penurunan garam dalam bentuk emulsi yang masih diterima secara rasa dibandingkan dengan target, dan kemudian mendapatkan emulsi dan viskositas yang paling stabil dalam aplikasi sup jagung. Pada penelitian tahap I, dibuatemulsi dengan tiga konsentrasi minyak yang berbeda (23, 28, dan 33\%) dengan konsentrasi garam dan bahan penstabil yang konstan. Hasil penelitian menunjukkan bahwa emulsi dengan 33\% minyak secara signifikan lebih kental, sementara emulsi dengan kadarminyak $23 \%$ ditemukan menjadi kurang asin $(\alpha=0,05)$. Emulsi dengan kadar minyak $28 \%$ dipilih untuk dilanjutkan pada stage 2 karena mempunyai keasinan dan viskositas yang baik. Penelitian tahap II, jenis dan konsentrasi bahan pengental (1 dan 2\% tapioka; 0,1 dan 0,2\% xanthan gum), dan instant soy protein (ISP) $(0,5 ; 1,0$; dan 1,5\%) diterapkan ke dalam emulsi dengan $28 \%$ kandungan minyak. Viskositas dan stabilitas emulsi secara signifikan dipengaruhi oleh konsentrasi bahan penstabil. Formulasi dengan emulsi minyak 28\%, dan 0,1\% xanthan gum serta 0,5\% ISP ini diaplikasikan dalam pembuatan sup jagung. Hasilnya pengurangan $25 \%$ natrium klorida dicapai tanpa mengurangi rasa a sin secara signifikan.
\end{abstract}

Kata kunci: emulsi o/w, evaluasi sensori, natrium klorida, pengurangan garam, sup jagung

\section{INTRODUCTION}

Increased sodium intake portion has been proven to have a tight relation to high blood pressure. Two thirds of cardiovascular disease (CVD) and half of stroke cases were caused by high

*Corresponding Author:

E-mail: melanie.cornelia@uph.edu blood pressure (He and MacGregor, 2009). According to World Health Organization (WHO, 2012), consumers have been adapted to the high salt level, which makes the consumers' perceptions towards low-sodium food products to be less palatable.

Researchers have developed several methods to reduce sodium intake. One of those is to substitute sodium in the table salt with other salts, such as potassium and calcium chloride (Busch et 
al., 2013). Nevertheless, other salts have mixed tastes that are usually described as bitter, medicinal, or unpleasant, which limit their use (Heidolph et al., 2011). Other researches carried out a study that salt intake could be reduced over period of time or reduction by stealth (Torrico et al., 2015). In their studies, the consumption of sodium was reduced gradually per week without detected by the consumer, which resulted in lower threshold towards saltiness. However, reduction by stealth is considered as a slow method and only reducing small amount of sodium intake. As drawbacks of those several methods have been studied, other salt reduction technique is desired to be evaluated.

One recommended strategy to reduce sodium in foods is modifying the food matrix properties which can affect sodium release and saltiness perception. Noort et al. (2010) modified the matrix of solid food, which was bread, by concentrating sodium within small regions of the bread through layering the salted and unsalted dough. On the other hand, Busch et al. (2013) explained that in liquid food, the modification of matrix system could be accomplished by the use of inert fillers that concentrate salt in the aqueous phase, which can also be applied to emulsion systems.

An emulsion is a mixture of two or more liquids that are immiscible, in which one liquid is dispersed in the other (Frasch-Melnik et al., 2010). Lad et al. (2012) studied that soup prepared with oil in water emulsion base was perceived saltier than soup without emulsion. Thurgood and Martini (2010) also found an enhancing effect of oil in saltiness perception in $20 \%$ oil in water emulsions. The application of oil in water emulsion is expected to "invisibly" reduce sodium intake without compromising the saltiness of the food product. In this research, the salt reducing method through oil in water emulsion will be evaluated and applied into food system.

\section{MATERIALS AND METHODS}

\section{Materials}

Materials used in this research were palm oil (Tropical, Indonesia), food grade sodium chloride salt crystalline (+99\%) (Cheetam garam Indonesia), tapioca starch (National Starch, USA), corn kernel (Indonesia), xanthan gum (Jungbunzlauer Switzerland).

\section{Emulsion preparation for research stage I and II (Lad et al., 2012; Suzuki et al., 2014 with modification) \\ The first stage was aimed to obtain the concen-} tration of oil phase in the emulsion that yields the highest saltiness. In the second stage, the best result from stage one was treated with different type and concentration of thickening agent and emulsifier concentration to obtain the most stable emulsion with appropriate viscosity for soup application. In research stage I and II, aqueous phase was prepared by weighing and premixing salt, instant soy protein isolate (ISP) (Shandong Shinoglory, China), and tapioca starch. In this research, ISP was used instead of pea protein isolate (PPI) because ISP have more suitable taste profile than PPI. The concentration of salt, SPI, and tapioca starch used were constant, which are $1 \%$, and was calculated based on the total weight of the emulsion. The dry mixed materials were stirred into distilled water gradually. In this research, heat were used to improve solid phase dissolution in aqueous phase. Aqueous phase was heated and stirred until $65^{\circ} \mathrm{C}$. After reaching the desired temperature, stirring was continued for two minutes. Meanwhile, the oil phase was prepared by weighing palm oil with the percentages of 23,28 , and $33 \%$ of the total weight of the emulsion. Oil phase was added into the aqueous phase. Sample then homogenized at $4000 \mathrm{rpm}$ for four minutes using high shear mixer (Silverson, USA) then cooled at room temperature $\left(27^{\circ} \mathrm{C}\right)$. The emulsion produced would be analyzed further for its viscosity, droplet size, and sensory property.

The concentration of oil phase selected for research stage II was the one perceived as significantly saltier in the stage I. The concentrations of tapioca starch as thickening agent used in the second stage were 1.0 and $2.0 \%$ of the total emulsion; meanwhile the concentrations of xanthan gum (Jungbunzlauer, Swiss) as thickening agent were 0.1 and $0.2 \%$ of the aqueous phase. The aqueous phase of emulsion stabilized by tapioca starch was prepared using the same method as aqueous phase preparation in the research stage $I$. Meanwhile, the aqueous phase of emulsion stabilized by xanthan gum was prepared by weighing and premixing dry materials, such as salt, SPI, and xanthan gum. The dry mixed materials were gradually stirred into distiled water. Aqueous phase was heated and stirred until $70^{\circ} \mathrm{C}$. After reaching the temperature, stirring was continued for two minutes. In stage II, due to different concentrations of emulsifier and stabilizer, higher temperature was used to increase the solubility of emulsifier and stabilizer. In stage II, oil phase was added into the aqueous phase. Sample then pre-homogenized at $4000 \mathrm{rpm}$ for four minutes using high shear mixer (Silverson, USA) then emulsion was homogenized using sonicator for five minutes and cooled in room temperature $\left(27^{\circ} \mathrm{C}\right)$. The emulsions were analyzed further for its stability, viscosity, and droplet size. Corn puree and soup preparation

Corn puree was prepared by scraping sweet corn kernels from the cob prior to steaming. After steamed for 15 minutes, corn kernels were blended 
with water with the ratio corn to water of $3: 1$ (w/w). Corn puree was filtered using tea strainer with size of $595 \mu \mathrm{m}$. Corn soup was prepared by adding emulsion into the puree with the ratio of $1: 1(w / w)$.

\section{Droplet size measurement (Rietberg et al., 2012 with modification)}

Emulsions were imaged around 24 hours after production on a light microscope (Olympus. USA). There was a modification of this method in this research. The modification was sample dilution followed by homogenization. The high number of droplets in the field of view would cause overlap and prevent counting, thus, requiring dilution. Sample $(200 \mu \mathrm{L})$ was pipetted into $4 \mathrm{~mL}$ of distiled water, covered with Parafilm, and repeatedly inverted until homogenous. Two $\mu \mathrm{L}$ of diluted sample was pipetted onto a glass microscopy slide and covered with a coverslip. Samples were imaged with a $400 x$ total magnification and captured with camera (Olympus, USA). Two slides per samples were prepared and two images per slide were taken, 30 droplets were measured for each evaluation. Evaluation were conducted in three replications.

\section{Viscosity measurement (Daubert and Farkas, 2013)}

Emulsion viscosity measurements were conducted with viscometer (Brookfield, USA). Emulsions were taken around 4 hours after production. Emulsions were loaded in a $200 \mathrm{~mL}$ beaker glass at room temperature $\left(27^{\circ} \mathrm{C}\right)$. Viscosity of emulsion was measured using a steady-state flow procedure with shear rates from 0.3 to $100 \mathrm{rpm}$, using appropriate spindle. Each emulsion was evaluated in duplicate. Evaluation were conducted in two replications.

Sensory evaluation (Lawless and Heymann, 2010; Rietberg et al., 2012 with modification)

Sensory evaluation was conducted at the same day of sample production by selected panel. There were two types of sensory evaluation, first was magnitude estimation testing and attribute ranking test. Twenty individuals consisted of 10 males and 10 females were selected and trained for the evaluation of saltiness. The panel have been selected through prescreening step, including evaluation of health conditions, personal preferences, food allergy, and capability to estimate proportions. Additionally, the trained panel have been given several training and tests, such as five basic tastes recognition and intensity test of the basic tastes. Selected panel have the value of BET of salty taste at the range of $0.005-0.017$. Emulsions were presented in $10 \mathrm{~mL}$ servings in $30 \mathrm{~mL}$ shot glass labeled with a random three-digit blinding code. Panel were told to take each sample into their mouths, swish for ten seconds, and evaluate for saltiness. Panelists were instructed to rinse their mouth before taking another sample according to the following procedure: take a bite of plain cracker and rinse with water to clear the palate and empty the mouth of cracker pieces.

\section{Experimental design and statistical analysis}

The experimental design of the research stage I was completely randomized single factor design with three levels, which was percentage of oil phase in the emulsion. The experimental design of the research stage II was completely randomized factorial design with two factors, which were three concentrations of SPI as emulsifier and two levels of starch and xanthan gum as thickening agent concentration in the emulsion. Experimental results of stage I were analyzed using a one way anova to determine difference in emulsion viscosity between different oil concentration. Experimental results of stage II were analyzed using two way anova to determine differences in emulsion viscosity and stability between different type of stabilizers and emulsifiers.

\section{RESULTS AND DISCUSSION}

\section{Droplet size of emulsion in research stage I}

The result of droplets measurement of emulsion with different oil concentrations is shown in Table 1.

Table 1. Droplet size of emulsion with different oil concentration

\begin{tabular}{cc}
\hline Concentration of Oil $(\%)$ & Diameter Size $(\mu \mathrm{m})$ \\
\hline 23 & $11.49 \pm 7.11$ \\
28 & $13.20 \pm 8.66$ \\
33 & $11.52 \pm 6.79$ \\
\hline
\end{tabular}

This result shows that emulsion with different concentration of oil had a narrow range of droplet size, with relatively large standard deviations. The size and variance of emulsion droplets diameter might be influenced by the method of homogenization during emulsification and not by the oil concentration. Additionally, the sample size was relatively small, which leads to large numbers of standard deviations. Rietberg et al. (2012) stated that the water in oil emulsion droplet size between few formulas with different oil concentration had no significant difference each other. Additionally, Lad et al. (2012) reported that oil in water emulsion and water-in-oil-in-water emulsion were compared well in term of droplet size. These authors showed that different structures of emulsion were still producing narrow range of droplet size. According to Stobiecka et al. (2006), the size of milk fat globules more affected by the effectives of the homogenization process and not affected by fat concentration. 


\section{Emulsion viscosity with different oil concen-} tration

The viscosity of emulsion with different oil concentration was measured using viscometer and the result is shown in Figure 1.

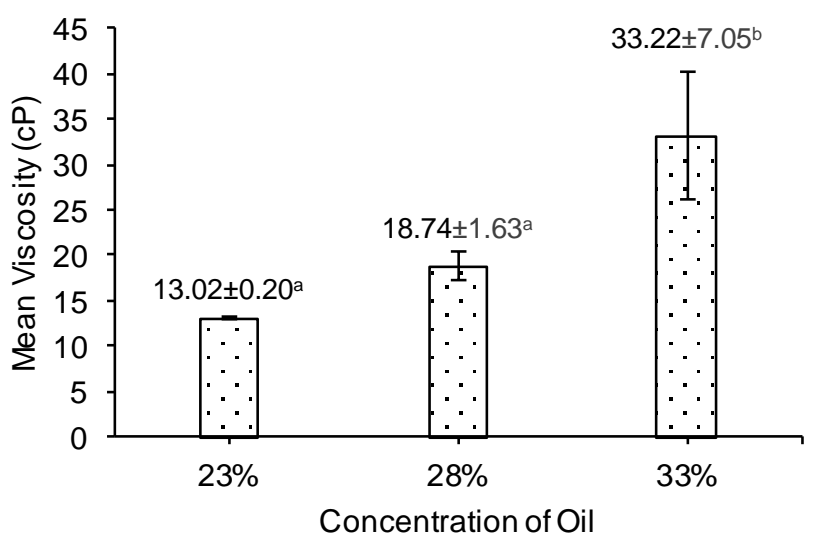

Note: Different superscript letter shows significant difference $(\alpha=0.05)$

Figure 1. Viscosity of emulsion with different oil concentrations

The viscosity of emulsions with 23,28 , and $33 \%$ oil concentration were $13.02,18.74$, and 33.22 CP respectively. After processed using ANOVA, it is revealed that emulsion with $33 \%$ oil was significantly more viscous than 23 and $28 \%(\alpha=0.05)$. This result implied that the increasing of oil content would lead to the increasing of viscosity. This makes the emulsion with $33 \%$ oil concentration has the highest viscosity among other emulsions. Stobiecka et al. (2006) studied that the viscosity of beverage emulsion was increased as the oil phase concentration increased. Previous study about milk rheological also observed that the viscosity of milk varied linearly with fat content (McSweeney and Fox, 2009).

\section{Saltiness perception of emulsion with different oil concentrations}

Based on the statistical analysis result of Magnitude Estimation Scaling test, emulsion with oil concentration of $23 \%$ was significantly less salty than 28 and $33 \%$. Meanwhile, emulsions with $28 \%$ and $33 \%$ oil concentration were not significantly different in saltiness $(\alpha=0.05)$. The statistical result indicates that higher oil concentration provides higher saltiness perception. This might be related with the fact that salt is soluble in water, yet insoluble in lipid. Hence, higher oil concentration, which means there is less water in the aqueous phase, might affect the dilution of the aqueous phase in the oral processing. It is possible with the same salt concentration in the mouth, the amount of salt diluted in saliva is more concentrated when there is less water in the emulsion.

Other studies related to this research also reported that as oil phase is increasing, the saltiness of the emulsion is perceived higher (Torrico and Prinyawiwatkul, 2015). Torrico and Prinyawiwatkul (2015) studied that in both $\mathrm{NaCl}$ and $\mathrm{KCl}$, the increasing oil concentrations of oil in water emulsion increased the intensity of salty taste at various salt concentrations. Lawrence et al. (2012) evaluated the effect of composition and texture of emulsion in solid lipoprotein matrices towards the saltiness perception. They observed that the fat content in the milk primarily influences the saltiness perception. Suzuki et al. (2014) hypothesized oil contributes to mouth-coating in the tongue that delays the rinsing of water phase from tongue, which may increase the saltiness. Meanwhile, Scanlon and Sanders (2007) studied that fat contributes to activate $\mathrm{K}^{+}$channels in the taste bud and thus, increases the transmitter release. Moreover, the author also found that there is a fatty acid transporter in the taste bud that might be involved in moving fatty acids along the tastant into receptor cells.

\section{Droplet size of emulsion in researach stage II}

Droplet size of emulsions with different starch and emulsifier concentration is shown in Table 2, whilst droplet size of emulsions with different xanthan gum and emulsifier concentration is shown in Table 3. The range of droplet size was narrow, which was between 9.06 and $11.46 \mu \mathrm{m}$, with standard deviations between 3.28 and $4.96 \mu \mathrm{m}$. The droplet size, however, was not a parameter to determine the chosen formula. The variance of droplet size in the stage II (refer to Table 2). was observed to be lower than the droplet size in the stage I This result obtained might be due to the sonication process was applied as homogenization in the stage II, which led to more uniform droplet size.

Table 2. Droplet size of emulsions with different tapioca starch and emulsifier concentration

\begin{tabular}{ccc}
\hline $\begin{array}{c}\text { Emulsifier } \\
\begin{array}{c}\text { Concentration } \\
(\%)\end{array}\end{array}$ & $\begin{array}{c}\text { Starch } \\
\text { Concentration } \\
(\%)\end{array}$ & $\begin{array}{c}\text { Diameter } \\
\text { Size } \\
(\mu \mathrm{m})\end{array}$ \\
\hline 0.5 & 1 & $9.06 \pm 3.34$ \\
& 2 & $11.17 \pm 3.84$ \\
1.0 & 1 & $11.43 \pm 4.96$ \\
& 2 & $10.37 \pm 3.28$ \\
1.5 & 1 & $11.05 \pm 3.58$ \\
& 2 & $11.46 \pm 4.33$ \\
\hline
\end{tabular}


Table 3. Droplet size of emulsions with different xanthan gum and emulsifier concentration

\begin{tabular}{ccc}
\hline $\begin{array}{c}\text { Emulsifier } \\
\begin{array}{c}\text { Concentration } \\
(\%)\end{array}\end{array}$ & $\begin{array}{c}\text { Xanthan Gum } \\
\text { Concentration } \\
(\%)\end{array}$ & $\begin{array}{c}\text { Diameter } \\
\text { Size } \\
(\mu \mathrm{m})\end{array}$ \\
\hline 0.5 & 0.1 & $11.23 \pm 4.24$ \\
& 0.2 & $10.04 \pm 3.51$ \\
1.0 & 0.1 & $11.14 \pm 4.32$ \\
& 0.2 & $10.49 \pm 3.94$ \\
1.5 & 0.1 & $10.39 \pm 3.56$ \\
& 0.2 & $10.47 \pm 3.45$ \\
\hline
\end{tabular}

One of other studies relating to this research which conducted by Rietberg et al. (2012), was obtained emulsion with the range size of 0.34 until $0.43 \mu \mathrm{m}$ with standard deviations range of 0.15 until $0.23 \mu \mathrm{m}$. These authors used high pressure homogenization after they performed high shear mixing towards the emulsion. This implies that different method of homogenization could reduce the size of emulsion droplets, as discussed in the research stage I. According to McClement (2005), the variance of droplet size could be reduced by performing double homogenization process.

\section{Emulsion viscosity with different starch and emulsifier}

The viscosity of emulsions with different tapioca starch and emulsifier concentration is shown in Table 4. Based on the statistical analysis result, emulsions with tapioca starch concentration of $1 \%$ were significantly less viscous than $2 \%(\alpha=0.05)$.

Table 4. Viscosity of emulsions with different starch and emulsifier concentration

\begin{tabular}{ccc}
\hline $\begin{array}{c}\text { Emulsifier } \\
\text { Concentration (\%) }\end{array}$ & $\begin{array}{c}\text { Starch } \\
\text { Concentration (\%) }\end{array}$ & $\begin{array}{c}\text { Viscosity } \\
(\mathrm{cP})\end{array}$ \\
\hline 0.5 & 1 & $16.27 \pm 2.26^{\mathrm{a}}$ \\
& 2 & $72.47 \pm 3.93^{\mathrm{a}}$ \\
1.0 & 1 & $18.76 \pm 1.06^{\mathrm{ao}}$ \\
& 2 & $53.74 \pm 2.22^{\mathrm{c}}$ \\
1.5 & 1 & $24.61 \pm 1.92^{\mathrm{D}}$ \\
& 2 & $83.53 \pm 0.44^{\mathrm{e}}$
\end{tabular}

Note: Different superscript letter shows significant difference $(\alpha=0.05)$

The viscosity of emulsions with different tapioca starch and emulsifier concentration is shown in Table 5. By observing the statistical analysis of emusion viscosity with different xanthan gum and emulsifier concentration, it is found that emulsions with xanthan gum concentration of $0.1 \%$ were also significantly less viscous than $0.2 \%$. These results show that thickening agent concentration had a significant effect towards the viscosity of the emulsion. According to Philips and Williams (2009), thickening agent is one of texture modifiers that increases the viscosity of emulsion continuous phase. Thus, the increasing of thickening agent concentration will lead to the increasing of the viscosity as well. Statistical analysis shows that the emulsions stabilized by xanthan gum were significantly more viscous than those stabilized by tapioca starch $(\alpha=0.05)$. According to Sworn et al. (2009), xanthan gum has complex intermolecular aggregations through hydrogen bonding and polymer entanglements, which leads to stiff molecules that result in high viscosity and accounts for the outstanding suspension stabilizing properties.

Table 5. Viscosity of emulsions with different xanthan gum and emulsifier concentration at day seven

\begin{tabular}{ccc}
\hline $\begin{array}{c}\text { Emulsifier } \\
\begin{array}{c}\text { concentration } \\
(\%)\end{array}\end{array}$ & $\begin{array}{c}\text { Xanthan Gum } \\
\text { Concentration } \\
(\%)\end{array}$ & $\begin{array}{c}\text { Viscosity } \\
(\mathrm{cP})\end{array}$ \\
\hline 0.5 & 0.1 & $94.05 \pm 3.17^{\mathrm{a}}$ \\
& 0.2 & $547.67 \pm 9.95^{\mathrm{a}}$ \\
1.0 & 0.1 & $144.53 \pm 1.40^{\mathrm{D}}$ \\
& 0.2 & $1109.00 \pm$ \\
1.5 & 0.1 & $31.23^{\mathrm{e}}$ \\
& 0.2 & $187.58 \pm 8.39^{\mathrm{c}}$ \\
& & $1547.70 \pm 14.50^{\mathrm{r}}$ \\
\hline $\begin{array}{c}\text { Note: Different superscript letter } \\
\text { difference ( } \alpha=0.05)\end{array}$ & shows significant
\end{tabular}

The viscosity of emulsions increased signifycantly as the increasing emulsifier concentration applied $(0.5,1.0$, and $1.5 \% \mathrm{SPI})$. It is possible when the Soy Protein Isolate (SPI) which acts as emulsifier heated, it underwent some gelation process. Thus, as the SPI increased, the more gelation occurred and the viscosity was increased. According to Nishinari et al. (2014), when soy protein heated, the $\beta$-sheet formation is encouraged andthus, leading to network formation or known as gelation.

\section{Stability of emulsion}

Table 6 and 7 show the separation fraction of the emulsions at day seven. Based on the statistical analyses, the stability of emulsions was significantly affected by the concentration of thickening agents $(\alpha=0.05)$. As the thickening agent concentration increased, the separation of emulsion was found to be decreasing. It is also observed that at lower concentration of thickening agents, i.e. tapioca starch and xanthan gum, the increasing of emulsifier concentration produced more stable emulsions.

Meanwhile, at higher concentration of thickening agents, the concentration of emulsifier was found not to affect the stability of emulsion signifycantly. These results might be obtained due to the emulsions with higher thickening agent concentration had significantly thicker systems, as discussed above, which made the effect of emulsifier towards emulsion viscosity becomes insignificant. 
According to Sun et al. (2007), the combination of protein and polysaccharide provides a high surface activity and high viscosity system, as well as forms gel-like absorbed layers which can avoid the emulsion to separate. Furthermore, Sworn et al. (2009) stated that the in the emulsion stabilized by protein and polysaccharide, the system is more depending on the concentration of polysaccharide rather than the protein.

Table 6. Separation fraction of emulsions with different concentration of tapioca starch and emulsifier at day seven

\begin{tabular}{ccc}
\hline $\begin{array}{c}\text { Emulsifier } \\
\begin{array}{c}\text { Concentration } \\
(\%)\end{array}\end{array}$ & $\begin{array}{c}\text { Starch } \\
\text { Concentration } \\
(\%)\end{array}$ & $\begin{array}{c}\text { Separation } \\
\text { Fraction at Day } \\
\text { Seven }\end{array}$ \\
\hline 0.5 & 1 & $0.452 \pm 0.052^{\mathrm{C}}$ \\
& 2 & $0.085 \pm 0.014^{\mathrm{a}}$ \\
1.0 & 1 & $0.317 \pm 0.047^{\mathrm{b}}$ \\
& 2 & $0.062 \pm 0.013^{\mathrm{a}}$ \\
1.5 & 1 & $0.241 \pm 0.038^{\mathrm{D}}$ \\
& 2 & $0.063 \pm 0.008^{\mathrm{a}}$
\end{tabular}

Note: Different superscript letter shows significant difference $(\alpha=0.05)$

Table 7. Separation fraction of emulsions with different concentration of xanthan gum and emulsifier at day seven

\begin{tabular}{ccc}
\hline $\begin{array}{c}\text { Emulsifier } \\
\text { Concentration } \\
(\%)\end{array}$ & $\begin{array}{c}\text { Xanthan Gum } \\
\text { Concentration } \\
(\%)\end{array}$ & $\begin{array}{c}\text { Separation } \\
\text { Fraction at Day } \\
\text { Seven }\end{array}$ \\
\hline 0.5 & 0.1 & $0.050 \pm 0.014^{\mathrm{c}}$ \\
& 0.2 & $0.000 \pm 0^{\mathrm{a}}$ \\
1.0 & 0.1 & $0.033 \pm 0.012^{\mathrm{DC}}$ \\
& 0.2 & $0.000 \pm 0^{\mathrm{a}}$ \\
1.5 & 0.1 & $0.022 \pm 0.006^{\mathrm{ab}}$ \\
& 0.2 & $0.000 \pm 0^{\mathrm{a}}$ \\
\hline
\end{tabular}

Note: Different superscript letter shows significant difference $(\alpha=0.05)$

Based on statistical analysis, the most stable formula stabilized by xanthan gum, i.e. $0.5 \%$ SPI and $0.2 \%$ xanthan gum was significantly more stable compared to the most stable formula stabilized by starch, i.e. $1.5 \% \mathrm{SPI}$ and $2 \%$ starch. This shows that xanthan gum provided more stable emulsions compared to tapioca starch. The result of statistical analysis shows that the separation fraction of emulsions stabilized by tapioca starch and xanthan gum was found to have a tight correlation with their viscosity $(\alpha=0.01)$. The separation fraction of emulsions was decreasing as the viscosity of the system increases, which means the emulsions with higher viscosity were more stable. It is possible that emulsion droplets are trapped in the high viscosity system. This might limit the movements of droplets that lead to less coalescence, flocculation, creaming, and sedimentation occur in the emulsions. According to Taggart and Mitchell (2009), increasing the viscosity of system is one of effective ways to enhance the stability of emulsion, especially with respect to creaming.

\section{Application of emulsion on corn soup}

Table 8 shows the viscosity of emulsion mixed with corn puree at $70^{\circ} \mathrm{C}$. This data is compared to the viscosity of commercial corn cream soup at $70^{\circ} \mathrm{C}$, as shown in Table 9. Corn soup emulsion that has the closest viscosity to commercial cream soup is the one stabilized by $0.1 \%$ xanthan gum with $0.5 \%$ SPI.

Table 8. Viscosity of emulsion mixed with corn puree at $70^{\circ} \mathrm{C}$

\begin{tabular}{ccc}
\hline SPI (\%) & Xanthan Gum (\%) & Viscosity (cP) \\
\hline 0.5 & 0.1 & $3827 \pm 808$ \\
0.5 & 0.2 & $9158 \pm 1148$ \\
1.0 & 0.1 & $5483 \pm 1574$ \\
1.5 & 0.1 & $13630 \pm 1051$ \\
\hline
\end{tabular}

Table 9. Viscosity of commercial corn cream soup at $70^{\circ} \mathrm{C}$

\begin{tabular}{cc} 
at $70^{\circ} \mathrm{C}$ & \\
\hline Brand & Viscosity (cP) \\
\hline Brand $A$ & $3823 \pm 146$ \\
Brand $B$ & $3337 \pm 110$ \\
\hline
\end{tabular}

Emulsion with oil concentration of $28 \%$ and stabilized by $0.1 \%$ xanthan gum and $0.5 \%$ SPI was chosen to be applied into corn soup. Based on the statistical analysis result for the first attribute ranking test, soup with 1.5 and $1 \%$ salt and $1 \%$ salt emulsion were significantly different each other. As shown in Table 10, soup with oil in water emulsion salt had the saltiness intensity between soups without emulsions with 1 until $1.5 \%$ salt addition ( $\alpha=0.05)$. This result led to the second attribute ranking test with samples of soups added with 1.25 and $1.30 \%$ salt and $1.0 \%$ emulsion salt, as shown in Table 11. The statistical analysis result of the second ranking test indicates that soup with $1.30 \%$ salt was significantly perceived saltier than the other two soups $(\alpha=0.05)$. Since soup with $1.25 \%$ salt and $1 \%$ salt oil in water emulsion had no significant difference each other, it could be said that oil in water emulsion containing salt with this formula could reduce the usage of salt up to $25 \%$.

Table 10. Total score of ranking test of soup added with 1.0 and $1.5 \%$ salt and $1.0 \%$ emulsion salt for screening appropriate salt concentration

\begin{tabular}{cc}
\hline Salt Content in Soup & Total Score of Ranking Test \\
\hline $1.50 \%$ & $26^{\mathrm{a}}$ \\
$1.00 \%($ emulsion) & $55^{\mathrm{D}}$ \\
$1.00 \%$ & $69^{\mathrm{C}}$
\end{tabular}

Note: Different superscript letter shows significant difference $(\alpha=0.05)$ 
Table 11. Total score of ranking test of soup added with 1.25 and $1.30 \%$ salt and $1.0 \%$ emulsion salt

\begin{tabular}{cc}
\hline Salt Content in Soup & Total Score of Ranking Test \\
\hline $1.30 \%$ & $35^{\mathrm{a}}$ \\
$1.25 \%$ & $51^{\mathrm{D}}$ \\
$1.00 \%$ (emulsion) & $64^{\mathrm{b}}$
\end{tabular}

Note: Different superscript letter shows significant difference $(\alpha=0.05)$

\section{CONCLUSIONS}

The physical characteristics of oil in water emulsion containing sodium chloride including droplet size, viscosity, and stability have been evaluated. From this research, it is obtained that droplet size of oil in water emulsions was between 9.06 and $13.20 \mu \mathrm{m}$, with relatively large standard deviations. Meanwhile, the viscosity and stability of emulsion was significantly affected by oil content and concentration of thickening agent and emulsifier. Xanthan gum stabilized emulsions were found to be significantly more stable and more viscous compared to those stabilized by tapioca starch. The sensory property of the emulsions has been evaluated. Based on the results, oil in water emulsion containing sodium chloride was perceived saltier than sodium chloride solution with the same concentration. Furthermore, the increasing of oil content in the emulsion significantly increased the saltiness. Lastly, it is also found that when applied into corn soup, oil in water emulsion with $1.0 \%$ sodium chloride, $28 \%$ oil, $0.5 \% \mathrm{SPI}$, and $0.1 \%$ xanthan gum had no significant difference in term of saltiness with corn soup containing $1.25 \%$ sodium chloride. This implied that emulsion with this formula could reduce the usage of sodium chloride up to $25 \%$ without decreasing saltiness significantly.

\section{AKNOWLEDGEMENTS}

The author would like to thank to PT. Nutrifood Indonesia, Food Research and Development Department, which funding the research by providing materials and equipment used.

\section{REFERENCES}

Busch JLHC, Yong FYS, Goh SM. 2013. Sodium reduction: optimizing product composition and structure toward increasing saltiness perception. Trends Food Sci Tech 29: 21-34. DOI: 10.1016/j.tifs.2012.08.005.

Daubert CR, Farkas BE. 2003. Food Analysis Laboratory: Viscosity Measurement Using a
Brokefield Viscometer. 139-142. Springer US. DOI: 10.1007/978-1-4419-1463-7_20.

Frasch-Melnik S, Norton IT, Spyropoulos F. 2010. Fat-crystal stabilized W/O emulsions for controlled salt Release. J Food Eng 98: 437. DOI: 10.1016/j.jfoodeng.2010.01.025.

He FJ, MacGregor GA. 2009. A comprehensive review on salt and health and current experience of worldwide salt reduction programmes. J Hum Hypertens 23: 363-384. DOI: 10.1038/ jhh.2008.144.

Heidolph BB, Ray DK, Roller S, Koehler P, Weber J, Slocum S, Noort MWJ. 2011. Looking for my lost shaker of salt replacer: flavour, function, future. Cereal Foods World 56: 5-19. DOI: 10.1094/CFW-56-1-0005.

Lad M, Hewson L, Wolf W. 2012. Enhancing saltiness in emulsion based foods. Flavour 1: 13. DOI: $10.1186 / 2044-7248-1-13$.

Lawless HT, Heymann H. 2010. Sensory Evaluation of Food: Principles and Practices. $2^{\text {nd }} \mathrm{Ed}$. Springer, New York.

Lawrence G, Buchin S, Achilleos C, Berodier F, Spetier C, Courcoux P, Salles C. 2012. In vivo sodium release and saltiness perception in solid lipoprotein matrices. J Agr Food Chem 60: 5287-5298. DOI: 10.1021/jf204434t.

McClement D, Julian. 2005. Food Emulsions: Principles, Practices, and Technique. $2^{\text {nd }}$ Ed. CRC Press, BocaRaton.

McSweeney PLH, Fox PF. 2009. Advanced Dairy Chemistry: Lactose, Water, Salts, and Minor Constituents. 3rd Ed. 711-712. Springer, New York.

Nishinari K, Fang Y, Guo S, Phillips GO. 2014. Gums and Stabilisers for the Food Industry 17: The Changing Face of Food Manufacture: The Role of Hydrocolloids in "Properties and Applications of Soy Proteins". 28-32. The Royal Society of Chemistry, Cambridge, UK. DOI: 10.1039/9781782621300-00028.

Noort MWJ, Bult, JHF, Stieger M, Hamer RJ. 2010. Saltiness enhancement in bread by inhomogeneous spatial distribution of sodium chloride. $\mathrm{J}$ Cereal Sci 52 378-386. DOI: 10.1016/j.jcs. 2010.06.018.

Philips GO, Williams PA. 2009. Introduction to Food Hydrocolloids. Woodhead Pub Ltd, New York.

Rietberg, MR, Rousseau D, Duizer L. 2012. Sensory evaluation of sodium chloride-containing waterin-oil emulsions. J Agr Food Chem 60: 4005-4011. DOI: 10.1021/jf2051625.

Scanlon VC, Sanders T. 2007. "Essentials of Anatomy and Physiology". $5^{\text {th }}$ Ed. F. A. Davis Company, Philadelphia. 
Stobiecka, A, Dluzewska E, Maszewska M. 2006. Effect of oil phase concentration on rheological properties and stability of beverage emulsions. Acta Sci Pol Technol Aliment 5: 147-156.

Sun C, Gunasekaran S, Richard MP. 2007. Effect of xanthan gum on physicochemical properties of whey protein isolate stabilized oil-in-water emulsions. Food Hydrocolloid 21: 555-564. DOI: 10.1016/j.foodhyd.2006.06.003.

Suzuki AH, Zhong H, Lee J, Martini S. 2014. Effect of lipid content on saltiness perception: a psychophysical study. J Sens Stud 29: 404412. DOI: $10.1111 /$ joss. 12121.

Sworn G, Danisco FSAS, France. 2009. Handbook of Hydrocolloids. Chpt 8 in "Xanthan Gum". $2^{\text {nd }}$ Ed. 186-195. CRC Press, New York.
Taggart P, Mitchell JR. 2009. Handbook of Hydrocolloids. Chpt 5 in "Starch". $2^{\text {nd }} E d .2$ 2nd Ed. 108-115. CRC Press, New York.

Thurgood JE, Martini S. 2010. Effects of 3 emulsion compositions on taste thresholds and intensity ratings of 5 taste compounds. J Sens Stud 25: 861-75. DOI: 10.1111/j.1745 459X.2010.0031 1.x.

Torrico DD, Prinyawiwatkul W. 2015. Psychophysical effects of increasing oil concentrations on saltiness and bitterness perception of oil-inwater emulsions. J Food Sci 80: 1885-1892. DOI: $10.1111 / 1750-3841.12945$.

[WHO] World Health Organization. 2012. Guideline: Sodium intake for adults and children. Available from: http://www.who.int/nutrition/publications /guidelines/sodium_intake_printversion.pdf. [2015 July 25th]. 